\title{
A Socialist Republican Theory of Freedom and Government
}

\begin{abstract}
:
In response to the republican revival of the ideal of freedom as non-domination, a number of 'radical,' 'labour' and 'workplace' republicans have criticised the limitations of Philip Pettit's account of freedom and government. This article proposes that the missing link in these debates is the relationship between republicanism and socialism. Seeking to bring this connection back into view in historical and theoretical terms, the article draws from contemporary radical republicans and the writings of Karl Kautsky and Rosa Luxemburg to propose a socialist republican theory of freedom and government. This consists of a conception of freedom as collective autonomy and a participatory democratic vision of a decentralised state with parliamentary institutions, the rule of law, worker-controlled workplaces, community-directed investment and a political culture of solidarity and public-spiritedness. This theory of socialist republicanism seeks to overcome the weaknesses and limitations of each respective independent theory and should appeal to republicans and socialists alike.
\end{abstract}

Key Words: republicanism, socialism, freedom, domination, democracy

(accepted at European Journal of Political Theory and published online first in 2018) 


\section{Introduction}

Philip Pettit's neo-Roman republican conception of liberty as non-domination has made a lasting contribution to debates in political philosophy over the nature of freedom. Domination occurs for Pettit when one party has the capacity to arbitrarily interfere with and control the possible choices of another on the basis of an opinion or an interest not shared by the dominated party. ${ }^{1}$ To be free, on this view, is to be free from the possibility of being subjected to the exercise of arbitrary power. In addition to its many adherents and supporters, it has also been met by a growing number of critics who question the democratic and egalitarian commitments of Pettit's particular appropriation of republican ideology. ${ }^{2}$ Many of these "radical" republicans affirm the importance of the reconstruction of republican political thought, even though they remain critical of certain aspects of Pettit's interpretation. This article proposes that such criticisms are now longstanding, persuasive and constitute a "social" turn in republican political thought, which justifies reflection on the underlying principles and orientation of a narrowly defined neo-Roman republican tradition. It suggests that a more robust and compelling conception of freedom and government can be formulated through systematically reorienting the republican political project by drawing on the resources of republican and socialist political thought.

Radical republicans have identified a number of weaknesses and omissions in Pettit's neo-Roman republican project. Exemplary criticisms are those raised by Alex Gourevitch's “labour" republicanism, Michael Thompson's "radical" republicanism and Keith Breen's "workplace" republicanism. Gourevitch argues that Pettit and other neo-republicans are inattentive to modern forms of economic domination enacted through a system of wage-labour and private property. ${ }^{3}$ For Gourevitch, Pettit fails to address concerns of structural domination resulting from workers' lack of control over the productive assets of the economy and the conditions of their work activity. ${ }^{4}$ While formally free and equal, modern workers are forced to sell their labour to survive, which places them in a position of structural dependency. ${ }^{5}$ Michael Thompson contends that Pettit's focus on inter-agent forms of domination misses the centrality of routinised and systemic forms of domination in modern societies. ${ }^{6}$ Pettit's emphasis on the arbitrary exercise of power by agents overlooks the core republican insight of the dangers of social institutions arranged to systematically distort the public's perception and legitimise oligarchic systems. Keith Breen argues that the neo-republican strategy of a right of exit for employees fails to counter employer domination in the workplace. ${ }^{7}$ Workplace republicans such as Breen claim that the organisational structure of capitalist firms requires strict state regulation and the democratisation of workplaces to ensure worker voice and control within firms. ${ }^{8}$

All of these critics share a common concern for developing an adequate account of structural domination and enhancing popular participation in political and economic institutions. I claim that their criticisms of Pettit's theory of liberty as non-domination push in the direction of a reappraisal of this ideal from the perspective of a more fully developed socialist republican position. This article draws from contemporary radical republicans and the writings of Karl Kautsky and Rosa Luxemburg to propose one particular version of a socialist republican theory of freedom and government. Rather than be faithful to any single thinker's writings, my intention is for this theory to be normatively appealing through an amalgamation of different aspects of republican and socialist political thought. Other ways of integrating republican and socialist 
insights are possible and should be further explored. My claim is that the sketch of a theory presented here offers a persuasive picture of how a decent state and civil society could be organised and touches upon key desiderata articulated by republicans and socialists.

A socialist republican theory of freedom as collective autonomy consists of a concern with forces and structures of domination combined with an ideal of citizens sharing in public power and collectively determining the direction of public institutions. In contrast to strictly negative ideals of liberty, it understands democratic participation as an essential rather than an auxiliary component of political freedom. This theory of freedom as collective autonomy also captures a wider array of forms of structural domination occurring through capitalist market relations than Pettit's inter-agent account of domination. In particular, it calls for the elimination of domination occurring through the authoritarian organisational structure of workplaces and the operation of free market principles on structurally dominated workers.

Socialist republicans argue for a participatory democratic vision of a decentralised state with parliamentary institutions, the rule of law, worker-controlled workplaces, community-directed investment and a political culture of solidarity and publicspiritedness. They seek to combine the benefits of a democratic state oriented towards the common good with democratic controls placed over major economic institutions to counter forms of domination by powerful economic interests. The theory provides a more stable and compelling vision of the institutional framework of a post-capitalist society than the communist ideal of a stateless society due to its defence of the rule of law and an independent judiciary. Such a framework provides superior protections for minorities and dissident groups and is better able to deal with the inevitability of ongoing political conflict.

This article first analyses the historical relationship between republican and socialist political thought. It contends that there is no definitive incompatibility between the two and that points of intersection have been marginalised within traditional historiography on the subject. It then offers an account of freedom as collective autonomy and the proper organisation and role of a socialist republican state.

\section{Republicanism and Socialism}

A theory of socialist republicanism should not strike either republicans or socialists as a contradiction in terms. After all, republicans claim they offer a more progressive account of political liberty than liberals, one that would appeal to socialists while avoiding the pitfalls of a positive conception of liberty. ${ }^{9}$ From a socialist perspective, Rosa Luxemburg has stated that "every socialist is naturally a republican," implying that there is no necessary conflict between the two political ideologies. ${ }^{10}$ For many nineteenth century socialists, republicanism was an assumed shared point of departure, particularly concerning issues of anti-monarchism, political participation and popular control. ${ }^{11}$

Although scholars contest its origins, it is generally recognised that socialism is a post-French revolutionary political ideology that emerged in response to the political 
and economic inequalities arising from the Industrial Revolution and the dramatic transformation of modes of production and working life. ${ }^{12}$

Mark Bevir has traced the emergence of socialist ideas in the United Kingdom out of the republican tradition at the end of the nineteenth century. ${ }^{13}$ Despite the variety of radical parties and affiliations during this period, there was a substantial continuity between different populist groups. ${ }^{14}$ Some of the first socialist republicans saw their position as an extension of key republican principles, rather than a repudiation of the older civic republican tradition. ${ }^{15}$ The socialist critique of capitalist forms of work was framed partly in republican terminology. It claimed that capitalist forms of wagelabour created a condition of dependency and servitude for workers. During this period, radical political actors employed republican language for socialist ends in a number of political journals such as George Julian Harney's The Red Republican and McDouall's Chartist and Republican Journal.

In France, the attempt by radical republicans to establish a democratic and social republic during the 1848 Revolution was conceptualised in terms of advancing the previous gains of the 1789 Revolution into the social and economic domains. Radical republicans sought to distinguish themselves from bourgeois republicans such as Louis-Eugène Cavaignac who was responsible for the June Days massacre in 1848. In the minds of the revolutionaries, the republic should not only have a democratic political order, but should also embrace a new social order that would equalise material conditions through a "right to work" for every citizen. For politician, Alexandre Ledru-Rollin, the political republic had to be replicated in the heart of industry and production. ${ }^{16}$ Radical republicans viewed economic reforms that alleviated poverty and provided work for the poor as a necessary complement to democratic political institutions.

Despite the defeat of the radical republicans in 1848, this tradition continued in the Paris Commune of 1871, which Marx described as an attempt at the creation of a "social republic." The Commune is important for the Marxist tradition because this event provides one of the few instances in which Marx offers insight into his conception of a possible political structure of a post-capitalist polity. Marx describes the Commune as a "working class government" or "the political form at last discovered under which to work out the economic emancipation of labour." ${ }^{17}$ His writings on the Paris Commune reveal Marx at perhaps his most republican due to his emphasis on political participation and popular control. This democratic republicaninflected Marxism, which is indebted to the French socialist tradition and the Paris Commune, continues in prominent socialists such as Karl Kautsky and Rosa Luxemburg.

Republicanism experienced a rapid decline in the late $19^{\text {th }}$ century and was largely supplanted by socialism within radical circles. ${ }^{18}$ According to a certain reductive understanding of Marxism that existed within parts of the Second International, there was a tendency to view the political as epiphenomenal of more profound economic relations of production, a position which diverted attention away from traditional republican concerns. ${ }^{19}$ On this view, political considerations of changes in laws or forms of government was a distraction from the class struggle to gain control over the means of production. ${ }^{20}$ As part of the shift away from republicanism, socialists began to refer to the working class rather than the people; and social conditions rather than 
political institutions and civic virtue. Lenin's emphasis on organising a vanguard revolutionary party also marginalised the importance of mass participation in politics and popular control over elites as necessary requirements for revolutionary transformation. $^{\mathbf{2 1}}$

However, in addition to these changes in political perspective, one can also trace a deeper set of shared beliefs. Socialist commitments to working class control over productive assets in the economy developed out of republican concerns of domination by powerful political and economic elites. A political agenda of self-governance and freedom from domination led naturally in an era of industrialisation to a call for placing parts of the economy under democratic control. An ongoing concern for popular government, democratic forms of organisation and independence as absence of external control can also be traced through modern republicanism into the socialist tradition.

Karl Kautsky and Rosa Luxemburg are interesting cases of theorists who incorporated elements of socialist and republican political thought. During the German Revolution of 1918/19, Kautsky considered a democratic republic as "the indispensable political basis of the new commonwealth we wish to construct... yet it should be even more than that. It should become a socialist republic - a commonwealth in which there is no longer any place for the exploitation of man by man." ${ }^{22}$ Kautsky's socialist republican program at this time consisted of support for political democracy (parliamentary institutions, the rule of law and civil rights) combined with the socialist organisation of the economy and workers' councils in workplaces acting as centres of institutionalised pressure from below on parliament. Kautsky considered that democracy and socialism were the twin goals of the socialist movement. Yet in opposition to the Leninist interpretation of Marxism, Kautsky took up a democratic republic heritage within Marxism that argued for the importance of a central administrative apparatus, parliamentary democracy and the rule of law. For Kautsky, the state needed to be "completely transformed" to eliminate its militaristic and bureaucratic aspects. ${ }^{23}$ At the same time, socialists would need "to extend democracy from the political to the economic system" in order to transform the basis of a democratic republic "into a social republic, instigating a new era in the history of humanity." 24

Rosa Luxemburg also drew from republican themes and language, although her support for republicanism was more muted and did not extend to the institutional framework of a republican state. Luxemburg asserted that "the best bourgeois republic is no less a class state." ${ }^{, 25}$ Republicanism for her was more a slogan for agitation rather than a goal and desired form of government. Hannah Arendt and Stephen Eric Bronner overstate their case in arguing for Luxemburg as a republican in the sense of supporting republican state institutions. ${ }^{26}$ In Luxemburg's writings, republican language of the public realm, civic virtue and mass participation in politics was intermingled with ideas of class struggle, revolutionary politics and a Marxist critique of capitalism. Luxemburg matters for the socialist republican tradition due to her vision of a participatory self-determining society in which individuals would play a permanent and active role in directing public institutions. Luxemburg also theorised the importance of cultural transformation and socialist civic virtues in the struggle to overcome capitalism and construct a more egalitarian society. 
The intersection of socialism and republicanism as a meaningful set of ideas has been marginalised within traditional historiography in favour of forms of neo-Roman and civic republicanism. ${ }^{27}$ I contend that the task of rethinking the republican and socialist traditions is one we urgently need to undertake. In so doing, it is important to be mindful of how certain aspects of both traditions have proved inadequate when confronted with the realities of modern societies. ${ }^{28}$ The following sketch of a theory of socialist republicanism is an attempt to overcome certain limitations by synthesising different aspects of the two traditions.

\section{Freedom as Collective Autonomy}

A socialist republican theory of freedom as collective autonomy consists of a collective process of widespread participation in processes of self-governance through which individuals exercise direct control over the central institutions of society. This follows a participatory republican tradition that understands the republican ideal as the protection of people from the exercise of arbitrary power and their participation in a self-governing political community. ${ }^{29}$ Neo-Roman republicans such as Pettit are justifiably concerned with the condition of those subject to the arbitrary powers of others. However, these neo-republicans unduly restrict an account of freedom by focusing exclusively on the "negative" ideal of liberty as non-domination and overlooking the important historical role played by individuals taking part in power and participating in the rational determination of public life. ${ }^{30}$ What is significant for citizens is not only a condition of protection against the arbitrary exercise of power, but to actively shape the character and direction of public institutions through participating in processes of self-governance. A richer conception of freedom would combine concerns over dominating agents, structures and forces with an attentiveness to the requisite practices of deliberation and decision-making of free citizens. ${ }^{31}$ There are three major ways in which a socialist republican theory of freedom as collective autonomy seeks to further develop Pettit's ideal of freedom as non-domination. First, its conception of domination should be sufficiently expansive to capture socialist insights concerning the structural domination of capitalist relations of economic production on workers. ${ }^{32}$ It should also attend to forms of structural domination that occur through gender- and race-based forms of oppression. Second, this theory of domination should also include a dimension of ideological domination, which explains how workers' can be influenced to believe that unequal social institutions are structured in their best interests. Third, a theory of freedom as collective autonomy should include reference to the importance of notions of self-determination and active participation in government. For socialist republicans, political participation is an essential and constitutive dimension of freedom rather than an auxiliary function or an activity that merely secures the conditions of freedom properly understood.

\section{Structural Domination}

The scope of Pettit's neo-Roman republican political program is restricted to interagent forms of domination. Pettit has explicitly argued that he does not consider the operation of a market economy as inimical to freedom. For Pettit, a system that defines rights of private ownership, free exchange and limited state regulation over the economy would not constitute domination merely on the grounds that it produces 
inegalitarian outcomes. He believes that even though the effects of a market economy may limit and constrain the possible choices of individuals, this will not be a source of domination if "it is the cumulative, unintended effect of people's mutual adjustments." ${ }^{, 3}$ Pettit envisions the market as akin to a set of background conditions that could be said to constrain or condition an agent's freedom, but not to compromise it.

Socialist republicans would take issue with the restriction of the concept of domination to this purely personal and intentional sense of the term. ${ }^{34}$ Alex Gourevitch has drawn attention to structural forms of economic domination that could occur in the economic sphere through the unequal control of resources in spite of notionally equal political rights. ${ }^{35} \mathrm{He}$ argues that the non-subjective and impersonal forces of the labour market could impinge on citizens' freedom in a manner that could coherently be described as a form of structural domination. For Gourevitch, although the compulsion of workers to enter into employment contracts cannot be attributed to any single employer, the structure of the system is the result of conscious efforts to organise economic relations to increase the advantages that accrue to wealthy and powerful capitalists. Pettit obscures the normatively significant distinction between natural environmental factors and the outcomes of a human produced and contingent economic system. In the case of the latter, it is not entirely accurate to say that choice sets are "randomly distributed" or "unintended" because the operation of the system follows a certain logic and is created and sustained by human intervention.

Socialists republicans have also theorised this form of domination through Marx's critique of a system of wage labour. In Wage Labour and Capital, Marx analyses the systemic inequalities between labourers and capitalists in relation to employment contracts. Marx emphasised this economic exchange rests upon an unequal social relationship between two classes of people with different structural positions corresponding to different amounts of power and mobility. "The worker, whose only source of income is the sale of his labour-power," might be able to choose between different employers, but, Marx adds, they "cannot leave the whole class of buyers." "36 In her interpretation, Rosa Luxemburg argues that this situation represents one of structural domination in which individually uncoordinated, cumulative but unintentional actions lead to a condition of unfreedom for workers forced to sell their labour. While no single employer necessarily intends to dominate a particular worker, due to the "separation of labour-power from the means of production" the worker has no commodity to bring to the marketplace to exchange, nothing that is, "but to bring himself to market as a commodity, i.e. to bring his own labour-power." 37 Where productive assets in the economy are owned by a narrow class of elites and operated in their interests, workers remain in a state of general dependence on the class of capitalists as a whole.

Socialist republicans should also be concerned with other forms of structural domination that operate along the lines of race, gender and sexuality. The fight of earlier socialists against capitalism has never been separated from a broader social struggle, one which was inscribed in the Erfurt program in opposition to "all forms of exploitation and oppression, whether it is directed at a class, a party, a gender, or a race." ${ }^{, 38}$ While a full account of the specific dynamics of each type of structural domination, including their intersecting operation and effects, goes beyond the scope of this article, the theory should be sensitive to vulnerable groups who are 
disproportionately subject to the exercise of arbitrary power by virtue of their membership of a minority group. Pettit emphasises that a conception of freedom as non-domination is a pluralistic ideal and can be understood as a "partially common good: a common good from the point of view of each vulnerability class." $" 39$ As a result, he argues that advocates of freedom as non-domination are committed to advancing the freedom of vulnerable classes by counteracting specific forms of domination which occur to members of each group. Socialist republicans seek to expand rather than restrict the neo-Roman republican understanding of domination, and would be similarly attentive to counteracting the domination of all members of vulnerable classes.

\section{Ideological Domination}

A second form of domination for socialist republicans is the control that dominant groups exercise over cultural and ideological apparatuses. Through the ownership or control of the media, information services, cultural and educational institutions and other institutional forms of socialisation, dominant groups can promote their own particular understanding of reality as the norm. This refers to the manner in which social institutions shape subjects to have certain beliefs, desires and identities that accord with the status quo. Michael Thompson's concept of "constitutive domination" describes how domination can occur through the systematic distortion of perceptions of the public good to benefit the interests of a narrow circle of elites. ${ }^{40}$ This process supports other forms of domination by providing legitimising narratives justifying the necessity of systemic and routinised forms of domination such as wage labour and oligarchic political structures. This need not involve the arbitrary interference of any particular agent over another because through this process agents come to internalise certain norms and values without the need for overt forms of intrusion or repression.

Ideological domination occurs through the constitution of individuals' deep-seated mental structures rather than by interfering arbitrarily in their rational choices. This aspect of domination is less visible and measurable than direct interference and as a result its effects often go unnoticed. It allows dominant groups to create and reinforce unconscious barriers and obstacles to challenging unequal arrangements of social power. By presenting these as part of a natural order and state of affairs, a dominant ideology can be used to justify and legitimate oppressive social conditions. Such a theory of domination rests on a conception of the ideological formation of subjects through social institutions. Here, ideology refers to the way in which a subject's experience of reality is mediated by a more or less coherent system of ideas, which tends to reflect the dominant set of power relations in society. Through ideological domination, subjects accept positions of subordination within social hierarchies based on a belief in the justness or inevitability of this state of affairs. ${ }^{41}$ Luxemburg argued that during the German Revolution the bourgeoisie still exercised an ideological hold over the proletariat, which led them to eventually give up power and vote in a constituent assembly rather than maintain power in a council system. ${ }^{42}$

One key question that presents itself is what differentiates this form of domination from unobjectionable forms of social reproduction. When, in other words, do elites exercise undue or dominating power over social institutions compared to nondominating forms of influence. The conventional socialist response has been to 
identify a subject's real interests as opposed to their perceived interests within an oppressive system, however these may be determined. When the biases of a system are mobilised to obscure social reality and promote mystifications that distort a subject's real interests and naturalise the power of a dominant group, this system becomes dominating. However, the determination of such "real" interests has proved a stumbling block to theories of ideology critique, with both a Marxist scientific knowledge $^{43}$ and a Kantian use of critical reason ${ }^{44}$ attracting certain objections. ${ }^{45}$ While socialist republicans consider a concept of ideological domination to be an important component of a compelling understanding of modern forms of domination, more theoretical work is needed to better understand the operation of its normative dimension.

\section{Participation in Self-Government}

Pettit's account of non-domination is based primarily on a negative ideal of freedom "defined by a status in which the evils associated with interference are avoided rather than by access to the instruments of democratic control, participatory or representative." ${ }^{\prime 46}$ The most influential critics of Pettit's account of the ideal of liberty as non-domination have traditionally focussed on his account of domination rather than his argument that democratic participation has no "definitional connection with liberty." 47 While arguing for an expansion of our understanding of domination, prominent critics such as Alex Gourevitch have worked from within the negative liberty tradition. ${ }^{48}$

However, another group of critics have contested the historical accuracy and normative appeal of Pettit's ideal of liberty as non-domination. Alan Coffee has taken issue with the primarily "negative" formulation of republican liberty by Pettit and has contended that more emphasis should be placed on participation in self-government. ${ }^{49}$ Coffee distinguishes between a sphere of laws and a sphere of norms and argues that marginalised groups may be particularly vulnerable to the dominating effects of the latter if they are unable to participate in the shaping of these norms. K. Sabeel Rahman has also claimed that responses to modern forms of structural domination should begin with attempts to expand the political capacities of ordinary citizens. ${ }^{50}$ Keith Breen has argued that even Pettit himself must implicitly rely on a positive ideal of autonomy:

[his] understanding clearly goes beyond an 'absence of mastery by others' to embrace the 'presence' of a specific sort of 'self-mastery,' the ability of persons to independently deliberate over issues and to rationally determine their actions in conjunction with others. ${ }^{51}$

Following these criticisms, socialist republicans emphasise the positive dimensions of political freedom. Luxemburg argued that politics "must proceed step by step out of the active participation of the masses; it must be under their direct influence, subjected to the control of complete public activity. $" 52$ In the collective autonomy approach, democratic participation in shared processes of self-governance is an essential element of how freedom is understood. Socialist republicans envisage freedom as a collective practice and an ongoing struggle against forces and structures of domination. Rather than consider freedom as a particular status or condition of proof against domination, it is better conceived as the exercise of political capacities of self-determination. It is distinct from both liberal and neo-republican ideals of 
freedom due to the importance of ordinary citizens participating in political processes. For socialist republicans, Pettit's emphasis on the contestatory over the authorial moment of democratic politics overlooks the possibility of developing institutional mechanisms for citizens to increase their control at the early stages of agenda-setting and discourse shaping. To merely contest laws and policy that have been created by political elites abandons an important sphere of democratic control and makes do with a diminished capacity to influence political processes. ${ }^{53}$

Democratic participation is also an essential element of political freedom because of its educative function. Since freedom is a practice that must be learnt, participation in politics enables citizens to educate themselves and come to a better realisation of their opinions and interests. Luxemburg argued that "the working classes in every country only learn to fight in the course of their struggles." 54 While the "bourgeois class rule has no need of the political training and education of the entire mass of the people," socialism relies upon an active citizenry assuming greater control over their collective destiny. ${ }^{55}$ Participation in public life "is the life element, the very air without which it [socialism] is not able to exist." ${ }^{, 56}$ Citizens must "feel out the ground, try out, experiment, test now one way now another." ${ }^{, 57}$

This conception of freedom as collective autonomy is less vulnerable to a number of the classic criticisms of positive liberty than has been assumed. A major criticism levelled against positive liberty by both Isaiah Berlin and Philip Pettit is that it entails unappealing ideas of self-mastery and the rule of a perceived rational section of the community over another. ${ }^{58}$ Yet the ideal of collective autonomy outlined here of protection against domination and participation in self-government need not involve any such subordination. Nor does collective autonomy rely on a conception of a homogenous community and communitarian ideas of a political community clarifying a single set of shared values. Freedom understood as collective autonomy does not require fundamental agreement on a singular conception of the good life for citizens to participate in processes of self-government. It would be sufficient for citizens to understand themselves as free and equal citizens committed to an ongoing process of self-governance without any further stipulations concerning the essence of human beings or the inner telos of the human race.

\section{Socialist Republican Government}

\section{Socialist Republican Aims: Citizen Control and Equalising Power}

A socialist republicanism should articulate a conception of the role of the state and how it should be organised. Such an institutional framework should represent a desirable ideal for the organisation of political and economic life. In contrast to the communist aim of the dissolution or withering away of the state, socialist republicans argue that the institutions of the state should be submitted to the will of a democratic citizenry and oriented towards the common interest.

Socialist republicans believe that the institutions of the state, constitutionalism, a parliament and the rule of law are necessary for a durable and realistic form of politics. ${ }^{59}$ They recognise that any large, industrialised and complex polity which exists alongside other states in a global political system will require some form of 
central administrative apparatus. ${ }^{60}$ They do not view the state as an inherently oppressive institution that is merely an organ of class domination. As a result, they are less sceptical than communists towards suitably transformed state institutions, which would express the collective will of the people. While state institutions are susceptible to elite capture in which powerful economic interests dominate political life and direct state activity towards their private ends, the state is a site of struggle and a possible vehicle for citizens to express their democratic will. ${ }^{61}$

The two principal aims of a socialist republican state are 1) to enable citizens to exercise control over public institutions in order to direct them towards common interests and 2) to counter the domination of economic and political elites through balancing power relations between citizens.

The first aim for socialist republicans is to arrange public institutions in a manner that maximises the input and control that citizens can exercise over important sites of deliberation and decision-making. The liberal democratic state has historically been utilised principally by powerful economic interests in order to enact laws favourable to maintaining their interests. The struggle in and against the state should be viewed as one in which citizens mobilise to defend their interests through both state institutions and civil society groups. Public institutions should be considered as mechanisms through which citizens can organise collective action and express their collective will. This would require the state to be transformed from a set of institutions that is relatively closed and impenetrable to ordinary citizens to one that is susceptible to greater levels of citizen control. Marx wrote that "[f]reedom consists in converting the state from an organ superimposed upon society into one completely subordinate to it." ${ }^{\prime 2}$ For the state to be subordinate to its citizens means they would be able to exercise a degree of control over how it functions and impose a relevant direction on governmental processes.

Decision-making that occurs in state institutions should not only reflect the collective will of citizens and track their interests, it should also be causally connected to processes that enable citizens to have some say in how relevant decisions will be made. ${ }^{63}$ Benjamin Barber notes that although every citizen cannot take part in every relevant decision, the aim should be for citizens to participate "not necessarily at every level and in every instance, but frequently enough and in particular when basic policies are being decided and when significant power is being deployed." ${ }^{\circ 4}$ These principles of citizen control should also be extended from the governmental sphere to other central institutions of society such as workplaces, economic regulatory institutions and the army. Luxemburg argued that the citizenry should make "the entire political and economic life" its own and give it "a conscious, free, and autonomous direction." ${ }^{65}$ The aim of a socialist republican state should be to maximise the opportunities for citizens to collectively shape the underlying structures and conditions of their shared public life.

However, the creation of new participatory mechanisms will only result in the reorientation of public institutions towards common interests if the underlying balance of power between social classes is challenged and fundamentally shifted. The second aim of a socialist republican state should be an attempt to rebalance the terms of power between classes and organise a counterpower against the privileged position of economic and political elites. Disaffected citizens sense that representative 
institutions are dominated by a narrow circle of elites that control decision-making, which results in outcomes that are not in the interests of the majority of workers. In response to the domination of the democratic system by elites the power of ordinary workers should be expanded through enhancing their capacities for collective action. The private power of large corporations and wealthy individuals must be met with the organised power of workers through institutionalised channels that enhance their collective democratic agency.

The desire to subject the institutions of the state to the control of all citizens and to simultaneously empower workers against elites creates a tension within the theory between the universal category of "the citizen" and the narrower category of "workers." The version of socialist republicanism defended here seeks to hold on to the importance of both categories for different theoretical purposes. Unlike in some forms of socialism, socialist republicans do not advocate for a temporary form of class-rule in which non-workers would be excluded from political decision-making. In versions of workers' democracy proposed by Anton Pannekoek, for example, the sovereignty of workers' councils would entail the exercise of "workers power to the exclusion of the other classes." ${ }^{, 66}$ Karl Kautsky, on the other hand, convincingly argued that a society which sought to put an end to forms of exploitation based on class would require universalist political structures that enshrined democratic rights and protections for all citizens. ${ }^{67}$ In debates over the National Assembly during the German Revolution, Kautsky insisted on defending universal suffrage, parliamentary institutions, and an electoral strategy of workers' parties gaining a majority in parliament. The aim of a socialist republican state should be to guarantee the universal protection of civil liberties and democratic rights of participation. Luxemburg argued that "Social Democracy has always contended that it represents not only the class interests of the proletariat but also the progressive aspirations of the whole of contemporary society. It represents the interests of all who are oppressed by bourgeois domination." ${ }^{68}$ A socialist republican state must also ensure that there are institutional mechanisms available to workers that can act as a countervailing power against the potential rise of political and economic elites who have historically attempted to concentrate power in their own hands and sought private benefit from public goods. Having established citizen control over public institutions and equalising power between citizens as the two aims of a socialist republican state, I now turn to the proper organisation of the state to fulfil these aims.

\section{Transformation of the State}

Socialist republicans consider the basic institutional framework of a democratic republic - constitutionalism, parliamentary institutions, the rule of law - as an important starting point for a social republic. However, in his socialist republican political program put forward during the German Revolution, Karl Kautsky also recommended further extensive political and economic transformations to state structures. ${ }^{69}$ Kautsky sought to show how the state could be transformed from a militarised and hierarchical structure into an instrument that would express the collective will of ordinary citizens. For Kautsky:

The state mechanism that has existed until now must be completely refashioned [völlig umgestaltet]. The bureaucracy must be stripped of its power and many of its functions, and 
must be placed under the supervision/control of the democratic representatives of the people in the municipality, the provinces, the states and the nation. ${ }^{70}$

The central changes Kautsky recommended were the transformation of the standing army into a people's militia, the subordination of the executive to a legislature elected through universal suffrage, the socialisation of the economy and the granting of extensive rights of self-government to local bodies including policing, taxation, housing and basic social services. Kautsky disagreed with Lenin that the institutions of the modern state should be dissolved and replaced by some alternative of a "fundamentally different type" based on the Paris Commune. ${ }^{71}$ On this point, he considered that Marx's analysis of the Paris Commune needed to be updated for contemporary conditions. Kautsky agreed with the Commune's attempt at "the most comprehensive expansion of self-government, the popular election of all officials and the subordination of all members of representative bodies to the control and discipline of the organised people." 72 However, he considered that a basic technicaladministrative apparatus could not be completely "smashed," but rather should be subordinated to a people's assembly through which administrators would be subject to control by representatives of the people elected through universal suffrage.

There are three principles from Kautsky's analysis that could guide contemporary socialist republicanism: demilitarisation, decentralisation and democratisation. First, the state's repressive capacities have to be drastically reduced through the minimisation of expenditure on its standing army and police force. Rosa Luxemburg went so far as to argue that "the entire war and munitions industries must be abolished." ${ }^{, 73}$ Luxemburg and Kautsky both agreed that "[i]nstead of a standing army, there should be a people's militia." 74 The people's militia is a body of citizens organised for military service that would be called upon only in emergencies and for national self-defence. Recruits should receive training alongside their civilian occupations and only the most senior officials should be professional soldiers. These reforms were designed to eliminate the capacity of the state to wage an aggressive war and to threaten other nations. Instead of a balance of power to act as a deterrent to other states, Kautsky argued a socialist republican state should support the establishment of an international regulatory body such as the United Nations and encourage multinational co-operation in which different nations could "participate as equals amongst equals." 75 Through an "international agreement on disarmament" it was hoped that "the size of the people's militia could be "adjusted accordingly." sum, the "bureaucratic militaristic" aspects of the state should be transformed along with its foreign policy towards a pacifistic stance relying on international co-operation with military options used only as a last resort of self-defence. ${ }^{77}$

Socialist republicans also support a reorganisation of the police force that would reduce its political function, but one which would continue to enable the state to enforce its laws. Marx wrote very little about the nature of post-capitalist society and leaves us no firm indications on the question of whether a legal system would disappear in a socialist society following the withering away of the state. ${ }^{78}$ While some Marxists have inferred that the legal system was a bourgeois institution, Karl Kautsky considered that "law and order are preconditions to accomplishing socialism" and that "it is totally ridiculous to believe that law and order are necessary only in the interests of exploitation." ${ }^{, 79}$ Kautsky argued that "the state must also hand over policing powers to the municipalities and districts." ${ }^{80} \mathrm{In}$ this proposal, police 
would still be employed by local officials to enforce laws, but their political function of repressing opposition groups, stifling protests and supporting private property relations would be eliminated.

A second key transformation of the state is the devolution of decision-making power and authority according to a principle of subsidiarity. In order for people to exercise collective autonomy, power should be located at a local level where possible and only transferred to a central authority in cases where issues cannot be adequately dealt with at a local level. This forms part of a broader program to break up the centralised bureaucratic power of the state and minimise the potential for state apparatuses to dominate citizens. Kautsky advocated "immediately granting the right of extensive self-government ... to the municipalities, administrative districts and provinces. ${ }^{\prime 81} \mathrm{He}$ argued that a whole variety of political issues were manageable at a local level such as taxation, policing, housing, social services and certain types of food production.

A third principle of political transformation relates to the institutionalisation of pressure on parliament from below through civic organisations that mobilise democratic citizens. For Kautsky:

The introduction of a parliament is one aspect of democratization, but it is not sufficient in itself. Important as the dependence of the government on parliament may be, it leads to democratization only when it is accompanied by the growing dependence of parliament on the popular masses. $^{82}$

Kautsky emphasised the importance of a close relationship between democratic institutions and the organised masses. He believed that "a parliament that does not derive its support from the mass of the people is powerless. On the other hand, the people in a parliamentary state that leaves its fate exclusively in the hands of the parliament is likewise impotent." ${ }^{83}$ Kautsky believed that there should be institutionalised pressure from below in order to hold representatives accountable and struggle for the particular interests of the most oppressed in society. While Kautsky envisaged these as workers' councils which had arisen during the German Revolution, such institutions could take on a variety of different forms of civic associations that mobilise citizens and patrol parliamentary representatives.

These three principles would be incomplete without the most important aspect of transforming public institutions: the democratisation of workplaces and public control over the direction of the economy.

\section{Democratisation of the Economy}

Rosa Luxemburg argued that the aim of capitalist economies was "the enrichment of a small number of idlers," rather than "delivering to the public at large the means of satisfying all its needs." 84 She called for productive assets to be "taken into common property of the people" in order for them to be "national property... under the control of society." $" 85$ Yet while Luxemburg had a clear idea of the dangers of concentrated economic power, it was Kautsky who most fully developed an institutional proposal for the democratisation of the economy. Kautsky argued that a socialist republic should aim "to extend democracy from the political to the economic system" 86 This consisted of worker-managed workplaces combined with the creation of new 
economic institutions that would enable co-ordination across workplaces and industries and balance the interests of different sections of the community in the public steering of the economy. The aim of these arrangements for Kautsky was to avoid the undemocratic pitfalls of "statist" versions of socialisation such as the Soviet Union.

Workers exercising collective autonomy should have control over major decisions that affect their individual workplace such as the working environment and conditions of employment. Some form of workplace democracy is essential in which workers' committees would manage their workplaces. However, if ownership and control over each individual workplace were handed to workers directly this would create vast inequalities across different industries and might incentivise workers to benefit themselves at the expense of the public. While the democratic intervention of workers into their workplaces is important to provide them with a voice at the level of management, the rights of workers should be balanced with the need for broader coordination across workplaces and production for community needs. Therefore a second layer of co-ordinating organisations would be necessary to organise across workplaces and integrate them into a broader institutional structure. At a national level a new form of economic organisation would be required to assist with the direction of the economy as a whole. This institution would also be in charge of questions of public investment, infrastructure and broader questions of economic steering. Kautsky proposed that such an organisation would consist of one third workers' representatives, one third organised consumers and one third representatives of the state administration in order to adequately balance the interests of different sections of the community:

\footnotetext{
With each branch of production that is transferred from capitalist to State or municipal ownership, a new organization should be created, which would enable the workers and the consumers, as well as science [state officials], to exercise the necessary influence upon the adaptation of the processes of production. Such an organization would be quite different from State bureaucracy as we have hitherto understood it." 87
}

Public assets would be owned by the state but opened up to participatory mechanisms so they could as far as possible be managed at the municipal level and subject to democratic controls. Importantly for Kautsky, this new economic organisation would not be co-terminal with the state. Kautsky was adamant that socialisation should not be viewed as synonymous with nationalistion and state ownership: "The state is not the appointed instrument of socialization in all branches of industry." "branches of production or of communications serve narrow local ends" then "[m]unicipal ownership and management is the proper solution of the problem." Under a socialised economy, the municipality would become an important site of local management and control. Kautsky's plan was that a thoroughly decentralised and democratic vision of economic planning would avoid the injustices of a capitalist market system while also overcoming the inefficiencies and bureaucratism of Soviet state socialism. Unlike market socialists, Kautsky did not envisage a pricing system for the allocation of goods and services in a democratised economy. Instead, public services would be run for the benefit of consumers and any profits would be invested back into communal production.

The democratisation of the economy in a socialist republic would thus promote public control over economic production through a co-ordinated system of economic 
institutions that respected the self-governance of producers at the level of the individual workplace, but that enabled public control over the direction of the economy as a whole. I will now examine how these institutional transformations would need to be combined with parallel changes in political culture such that citizens would routinely act in ways that expressed solidarity for other citizens and publicspiritedness towards public institutions.

\section{Socialist Civic Virtues}

In 1917, reflecting upon the prospects for the Russian Revolution, Karl Kautsky wrote, "[i]n order to liberate themselves, the workers not only need certain material preconditions at their disposal and to be numerically strong; they also have to become new people, endued with the abilities that are required for the reorganisation of state and society." $" 90$ The problem could not be addressed by simply establishing new political and economic institutions as the oppressive relations were deeply rooted in the national psyche and could only be overcome through more profound changes of mentality.

The political transformation of the state would also require a corresponding shift in the political culture of its citizens. Luxemburg argued for the importance of a widespread change in social norms and patterns of behaviour to ensure the success of political change. Adopting the republican-inspired language of "socialist civic virtues," she considered that worker-controlled institutions would need to be supported by widely accepted socialist norms that would be common knowledge and followed as a matter of habit. Luxemburg argued that workers should direct themselves away from the egoism, individualism and competition that predominated in capitalist societies and towards socialist virtues of solidarity, public-spiritedness and self-discipline. She argued that "[s]ocialism in life demands a complete spiritual transformation in the masses degraded by centuries of bourgeois rule. Social instincts in place of egotistical ones, mass initiative in place of inertia, idealism which conquers all suffering." 91

Luxemburg rarely wrote about the requirements of a post-capitalist society, but in the following illuminating passage she outlines what she considered as the necessary changes in political culture:

From dead machines assigned their place in production by capital, the proletarian masses must learn to transform themselves into the free and independent directors of this process. They have to acquire the feeling of responsibility proper to active members of the collectivity which alone possesses ownership of all social wealth. They have to develop industriousness without the capitalist whip, the highest productivity without slavedrivers, discipline without the yoke, order without authority. The highest idealism in the interest of the collectivity, the strictest self-discipline, the truest public spirit of the masses are the moral foundations of socialist society, just as stupidity, egotism, and corruption are the moral foundations of capitalist society.... All these socialist civic virtues, together with the knowledge and skills necessary to direct socialist enterprises, can be won by the mass of workers only through their own activity, their own experience." 92

Adopting the republican language of civic virtue, but interpreting it as action in solidarity with other workers rather than as action aimed at preserving a state's institutions, Luxemburg put forward a vision of the oppressed classes exercising self- 
determination over public institutions. Such a cultural dimension is an important element in a broader program of a socialist republican theory of the state and civil society.

This article has sought to articulate a socialist republican ideal of freedom and government and has not outlined a political strategy of how such a socialist republic could be achieved from the position of many of today's liberal democracies. It has confined itself to sketch the outlines of a theory which will require further elaboration and development. The socialist republican viewpoint that I have developed here emerges with thinkers such as Marx, Kautsky and Luxemburg, but also draws on other ideas in the radical republican and Marxist traditions. Following the many sustained criticisms of a narrow and conservative reading of the republican tradition in Philip Pettit's neo-Roman republicanism, this article has argued for embracing the resources available within the socialist and republican traditions for articulating an appealing socialist republican vision of freedom and government.

\footnotetext{
${ }^{1}$ Pettit P (1997) Republicanism: A Theory of Freedom and Government. New York: Oxford University Press, p. 22.

${ }^{2}$ McCormick J (2011) Machiavellian Democracy. Cambridge: Cambridge University Press; Gourevitch A (2014) From Slavery To the Cooperative Commonwealth. Cambridge: Cambridge University Press; Thompson MJ (2018) Two faces of domination in republican political theory. European Journal of Political Theory 17(1): 44-64.

${ }^{3}$ Gourevitch, From Slavery To the Cooperative Commonwealth, p. 12; Gourevitch A (2013) Labour Republicanism and the Transformation of Work. Political Theory 41(4): 591-617.

${ }^{4}$ Pettit P (2007) A Republican Right to Basic Income? Basic Income Studies 2: 1-12.

${ }^{5}$ Gourevitch, From Slavery To the Cooperative Commonwealth, pp. 106-115.

${ }^{6}$ Thompson, Two faces of domination in republican political theory, p. 45.

${ }^{7}$ Breen K (2015) Freedom, republicanism, and workplace democracy. Critical Review of International Social and Political Philosophy 18(4): 470-485; Breen K (2017) Non-Domination, Workplace Republicanism, and the Justification of Worker Voice and Control. International Journal of Comparative Labour Law and Industrial Relations 33(3): 419-439.

${ }^{8}$ See also González-Ricoy I (2014) The Republican Case for Workplace Democracy. Social Theory and Practice 40: 232-254.

${ }^{9}$ Pettit, Republicanism, p. 141.

${ }^{10}$ Luxemburg R (1903) An anti-clerical policy of Socialism.

${ }^{11}$ Bonnell AG (1996) Socialism and Republicanism in Imperial Germany. Australian Journal of Politics \& History 42: 192-202, 195.

${ }^{12}$ See Boggs C (1995) The Socialist Tradition: From Crisis to Decline. London: Routledge, p. 2.

${ }^{13}$ Bevir M (2000) Republicanism, Democracy and Socialism in Britain: The Origins of the Radical Left. Journal of Social History 34: 353-360.

${ }^{14}$ Biagini E and Reid A (eds.) (1991) Currents of Radicalism: Popular Radicalism, Organised Labour and Party Politics in Britain, 1850-1914. Cambridge: Cambridge University Press, p. 1.

15 Thompson EP (1963) The Making of the English Working Class. London, Victor Gollancz, pp. 910913.

${ }^{16}$ Ledru-Rollin A (1848) Discourse on the debate over the labour law in the Assembly in 1848. In: Garnier J (ed) Le droit au travail à l'Assemblée, recueil de tous les discours prononcés dans cette mémorable discussion. Paris : Guillaumin, p. 123.

${ }^{17}$ Marx K (1977) The Civil War in France. In McLellan D (ed) Karl Marx: Selected Writings. Oxford: Oxford University Press, p. 589.

${ }^{18}$ Bevir, Republicanism, Democracy and Socialism in Britain, 354.

${ }^{19}$ Bonnell, Socialism and Republicanism in Imperial Germany, p. 199.

${ }^{20}$ McIvor M (2009) Republicanism, socialism and the renewal of the left. In: Callaghan J, Fishman N, Jackson B, and McIvor M (eds.) In Search of Social Democracy: Responses to Crisis and Modernisation. Manchester: Manchester University Press.

${ }^{21}$ Cf. Lih L (2008) Lenin Rediscovered: 'What is to be Done?' in Context. Chicago: Haymarket Books.

${ }^{22}$ Kautsky K (1919) Guidelines for a Socialist Action Program.

${ }^{23}$ Kautsky K (1919) Driving the Revolution Forward.
} 
${ }^{24}$ Kautsky K (1918) Demokratie oder Diktatur. Berlin: Paul Cassirer; Kautsky, Guidelines for a Socialist Action Program.

${ }^{25}$ Luxemburg R (1981) Zeit der Aussaat. In: Radczun G et al., eds. Gesammelte Werke Vol. 2. Berlin: Dietz, pp. 301-302.

${ }^{26}$ Arendt H (1968) Men in Dark Times. New York: Harcourt Brace and Company, p. 38; Bronner SE (2013) Red Dreams and the New Millennium: Notes on the Legacy of Rosa Luxemburg. In: Schulman $\mathrm{J}$ (ed) Rosa Luxemburg - Her Life and Legacy. New York: Palgrave Macmillan, pp. 11-20, 12.

${ }^{27}$ McIvor, Republicanism, socialism and the renewal of the left, p. 252.

${ }^{28}$ Goodin RE (2006) Folie Republicaine. Annual Review of Political Science 6(1): 55-76; Kirchheimer O (1987) On the Marxist Theory of the State. In: Tribe K (ed.) Social Democracy and the Rule of Law. Unwin Hyman.

${ }^{29}$ Honohan I (2002) Civic Republicanism. London: Routledge, pp. 75-76; Coffee A (2015) Two Spheres of Domination: Republican theory, social norms and the insufficiency of negative freedom. Contemporary Political Theory 14: 45-62, 46.

${ }^{30}$ Breen, Freedom, republicanism, and workplace democracy, p. 479.

${ }^{31}$ Rostbøll C (2008) Deliberative Freedom. Albany, NY: SUNY Press, p. 56.

${ }^{32}$ Gourevitch, Labour Republicanism and the Transformation of Work. Political Theory 41(4): 591617.

${ }^{33}$ Pettit P (2006) Freedom in the Market. Politics, Philosophy \& Economics 5(2): 131-149, 139.

${ }^{34}$ Pettit, Republicanism, p. 52.

${ }^{35}$ Gourevitch, Labour Republicanism and the Transformation of Work, pp. 600-608.

${ }^{36}$ Marx K (1977) Wage Labour and Capital. In Marx K and Engels F, Collected Works, Vol. 9, pp. 197-228, 210.

${ }^{37}$ Luxemburg R (2013) Introduction to Political Economy. In Hudis P (ed) The Complete Works of Rosa Luxemburg, Volume I: Economic Writings 1. London: Verso, p. 234.

${ }^{38}$ Kautsky K (1920) Das Erfurter Programm. Stuttgart: Dietz Nachf. Verlag.

${ }^{39}$ Pettit, Republicanism, p. 124.

${ }^{40}$ Thompson MJ (2018) The two faces of domination in republican political theory. European Journal of Political Theory 17(1): 44-64.

${ }^{41}$ Eagelton T (1991) Ideology: An Introduction. London: Verso, p. 5.

${ }^{42}$ Luxemburg R (2004) Our Program and the Political Situation. In Hudis P and Anderson KB (eds)

The Rosa Luxemburg Reader. London: Monthly Review Press, p. 367.

${ }^{43}$ Althusser L (1971) Ideology and Ideological State Apparatuses. Lenin and Philosophy and Other Essays. New York: Monthly Review Press, p. 129.

${ }^{44}$ Lukes S (1974) Power: A Radical View. London: Macmillan Press, p. 25.

${ }^{45}$ Hay C (2002) Political Analysis: A Critical Introduction. Basingstoke: Palgrave MacMillan, p. 183.

${ }^{46}$ Pettit, Republicanism, p. 30.

${ }^{47}$ Ibid.

${ }^{48}$ Gourevitch, From Slavery To the Cooperative Commonwealth, p. 65.

${ }^{49}$ Coffee, Two Spheres of Domination: Republican theory, social norms and the insufficiency of negative freedom.

${ }^{50}$ Rahman KS (2017) Democracy against domination: Contesting economic power in progressive and neorepublican political theory," Contemporary Political Theory 16: 41-64.

${ }^{51}$ Breen, Freedom, republicanism, and workplace democracy, p. 478.

${ }^{52}$ Luxemburg R (2004) The Russian Revolution. In Hudis P and Anderson KB (eds) The Rosa Luxemburg Reader. London: Monthly Review Press, p. 308.

${ }^{53}$ Rostbøll, Deliberative Freedom, p. 55.

${ }^{54}$ Luxemburg R (1910) The Next Step.

${ }^{55}$ Luxemburg, The Russian Revolution, p. 304.

56 Ibid.

${ }^{57}$ Ibid.

${ }^{58}$ Pettit, Republicanism, p. 81.

${ }^{59}$ Thompson MJ (2018) A Theory of Council Republicanism. In: Muldoon J (ed.) Council Democracy: Towards a Democratic Socialist Politics. London: Routledge, pp. 108-127.

${ }^{60}$ Kautsky K (1924) The Labour Revolution. London: Ruskin House, pp. 60-62.

${ }^{61}$ Pachter H (1984) Socialism in History: Political Essays. New York: Columbia University Press, pp. 45- 6; Kirchheimer O (1987) On the Marxist Theory of the State. In: Tribe K (ed.) Social Democracy and the Rule of Law. Unwin Hyman, p. 83. 
${ }^{62}$ Marx K (1977) Critique of Gotha Program. In McLellan D (ed) Karl Marx: Selected Writings. Oxford: Oxford University Press, p. 610.

${ }^{63}$ Cf. Pettit, Republicanism, pp. 11, 55.

${ }^{64}$ Barber B (2003) Strong Democracy: Participatory Politics for a New Age. Berkeley and Los Angeles, California: University of California Press, p. 151.

${ }^{65}$ Luxemburg R (2004) What Does the Spartacus League Want? In Hudis P and Anderson KB (eds)

The Rosa Luxemburg Reader. London: Monthly Review Press, p. 350.

${ }^{66}$ Pannekoek A (1927) Social Democracy and Communism.

${ }^{67}$ Kautsky K (1986) National Assembly and Council Assembly. In: Riddell J (ed.) The German Revolution and the Debate on Soviet Power. New York: Anchor Foundation.

${ }^{68}$ Luxemburg R (2006) Marxism or Leninism? In Reform or Revolution and Other Writings. Mineola, NY: Dover Publications, p. 94.

${ }^{69}$ Kautsky, Guidelines for a Socialist Action Program.

${ }^{70}$ Kautsky, Driving the Revolution Forward.

${ }^{71}$ Lenin VI (1974) The State and Revolution. In Collected Works, Vol 25. London: Progress Publishers, pp. 381-492, 405.

${ }^{72}$ Kautsky, Guidelines for a Socialist Action Program.

${ }^{73}$ Luxemburg R (2004) The Socialisation of Society. In Hudis P and Anderson KB (eds) The Rosa Luxemburg Reader. London: Monthly Review Press, p. 347.

${ }^{74}$ Kautsky, Guidelines for a Socialist Action Program.

${ }^{75}$ Ibid.

76 Ibid.

${ }^{77}$ Kautsky K (1922) Die proletarische Revolution und ihr Programm. Stuttgart: J. H.W. Dietz Nachf., p. 118.

${ }^{78}$ Lustgarten L, Socialism and the Rule of Law. Journal of Law and Society (1988) 15(1): 25-41.

${ }^{79}$ Kautsky, National Assembly and Council Assembly, p. 103.

${ }^{80}$ Kautsky, Guidelines for a Socialist Action Program.

${ }^{81}$ Ibid.

${ }^{82}$ Kautsky, The Bolsheviki Arising.

${ }^{83}$ Ibid.

${ }^{84}$ Luxemburg, The Socialisation of Society, p. 346.

${ }^{85}$ Ibid.

${ }^{86}$ Kautsky, Die proletarische Revolution und ihr Programm, 23.

${ }^{87}$ Kautsky, The Labour Revolution, p. 233.

${ }^{88}$ Ibid.

${ }^{89}$ Kautsky, Guidelines for a Socialist Action Program.

${ }^{90}$ Kautsky K (2010) Prospects of the Russian Revolution, Worker Weekly.

${ }^{91}$ Luxemburg, The Russian Revolution, p. 306.

${ }^{92}$ Luxemburg, What Does the Spartacus League Want?, p. 351. 


\section{References}

Althusser L (1971) Ideology and Ideological State Apparatuses. Lenin and Philosophy and Other Essays. New York: Monthly Review Press.

Arendt H (1968) Men in Dark Times. New York: Harcourt Brace and Company. Arendt H (2006) Between Past and Future: Eight Exercises in Political Thought. New York: Penguin Books.

Barber B (2003) Strong Democracy: Participatory Politics for a New Age. Berkeley and Los Angeles, California: University of California Press.

Bevir M (2000) Republicanism, Democracy and Socialism in Britain: The Origins of the Radical Left. Journal of Social History 34: 351-368.

Biagini E and Reid A (1991) Currents of Radicalism: Popular Radicalism, Organised Labour and Party Politics in Britain, 1850-1914. Cambridge: Cambridge University Press.

Boggs C (1995) The Socialist Tradition: From Crisis to Decline. London: Routledge. Bonnell AG (1996) Socialism and Republicanism in Imperial Germany. Australian Journal of Politics \& History 42: 192-202.

Bronner SE (2013) Red Dreams and the New Millennium: Notes on the Legacy of Rosa Luxemburg. In: Schulman J (ed) Rosa Luxemburg - Her Life and Legacy. New York: Palgrave Macmillan, pp. 11-20.

Breen K (2015) Freedom, republicanism, and workplace democracy. Critical Review of International Social and Political Philosophy 18(4): 470-485.

Breen K (2017) Non-Domination, Workplace Republicanism, and the Justification of Worker Voice and Control. International Journal of Comparative Labour Law and Industrial Relations 33(3): 419-439.

Coffee A (2015) Two Spheres of Domination: Republican theory, social norms and the insufficiency of negative freedom. Contemporary Political Theory 14: 45-62. Desmond M and Emirbayer M (2009) What is Racial Domination? Du Bois Review 6(2): 335-355.

Einspahr J (2010) Structural Domination and Structural Freedom: a Feminist

Perspective. Feminist Review 94: 1-19.

Engels F (1987) The Condition of the Working Class in England. London:

Hammondsworth.

González-Ricoy I (2014) The Republican Case for Workplace Democracy. Social Theory and Practice 40: 232-254

Goodin RE. (2006) Folie Republicaine. Annual Review of Political Science 6(1): 5576.

Gourevitch A (2013) Labour Republicanism and the Transformation of Work.

Political Theory 41(4): 591-617.

Gourevitch A (2014) From Slavery To the Cooperative Commonwealth: Labor and Republican Liberty in the Nineteenth Century. Cambridge: Cambridge University Press.

Harney J (1966) The Red Republican and the Friend of the People. New York, Barnes \& Noble.

Hay C (2002) Political Analysis: A Critical Introduction. Basingstoke: Palgrave MacMillan.

Honohan I (2002) Civic Republicanism. London: Routledge.

Kautsky K (1918) Demokratie oder Diktatur. Berlin: Paul Cassirer.

Kautsky K (1918) The Bolsheviki Rising. Accessed at https://www.marxists.org/archive/kautsky/1918/03/bolsheviki.htm 
Kautsky K (1919) Guidelines for a Socialist Action Programme. Accessed at https://www.marxists.org/archive/kautsky/1919/01/guidelines.html.

Kautsky K (1919) Driving the Revolution Forward. Accessed at https://www.marxists.org/archive/kautsky/1918/12/forward.html Kautsky K (1920) Das Erfurter Programm. Stuttgart: Dietz Nachf. Verlag.

Kautsky K (1922) Die proletarische Revolution und ihr Programm. Stuttgart: J. H.W. Dietz Nachf.

Kautsky K (1924) The Labour Revolution. London: Ruskin House.

Kautsky K (1986) National Assembly and Council Assembly. In: John Riddell (ed.), The German Revolution and the Debate on Soviet Power. New York: Anchor Foundation.

Kautsky K (2010) Prospects of the Russian Revolution, Weekly Worker, 14 January 2010. Accessed at https://weeklyworker.co.uk/worker/800/supplement-prospects-ofthe-russian-revolution/

Kirchheimer O (1987) On the Marxist Theory of the State. In: Tribe K (ed.) Social Democracy and the Rule of Law. Unwin Hyman.

Ledru-Rollin A (1848) Discourse on the debate over the labour law in the Assembly in 1848. In: Garnier J (ed.) Le droit au travail à l'Assemblée, recueil de tous les discours prononcés dans cette mémorable discussion. Paris : Guillaumin.

Lenin VI (1974) The State and Revolution. In Collected Works Vol 25. London: Progress Publishers.

Lih L (2008) Lenin Rediscovered: 'What is to be Done?' in Context. Chicago: Haymarket Books.

Lukes S (1974) Power: A Radical View. London: Macmillan Press.

Luxemburg R (1903) An anti-clerical policy of Socialism. Accessed at https://www.marxists.org/archive/luxemburg/1903/01/01.htm

Luxemburg R (1910) The Next Step. Accessed at https://www.marxists.org/archive/luxemburg/1910/03/15.htm

Luxemburg R (1981 [1910]) Zeit der Aussaat. In Radczun G et al., (eds) Gesammelte Werke Vol 2. Berlin: Dietz.

Luxemburg R (2004) What Does the Spartacus League Want? In Hudis P and Anderson KB (eds) The Rosa Luxemburg Reader. London: Monthly Review Press. Luxemburg R (2004) Our Program and the Political Situation. In Hudis P and Anderson KB (eds) The Rosa Luxemburg Reader. London: Monthly Review Press. Luxemburg R (2004) The Socialisation of Society. In Hudis P and Anderson KB (eds) The Rosa Luxemburg Reader. London: Monthly Review Press.

Luxemburg R (2004) The Russian Revolution. In Hudis P and Anderson KB (eds)

The Rosa Luxemburg Reader. London: Monthly Review Press.

Luxemburg R (2006) Marxism or Leninism? In Reform or Revolution and Other

Writings. Mineola, NY: Dover Publications.

Luxemburg R (2013) Introduction to Political Economy. In Hudis P (ed) The

Complete Works of Rosa Luxemburg, Volume I: Economic Writings 1. London:

Verso.

McCormick J (2011) Machiavellian Democracy. Cambridge: Cambridge University

Press.

McIvor M (2009) Republicanism, socialism and the renewal of the left. In Callaghan J, Fishman N, Jackson B, and McIvor M (eds) In Search of Social Democracy:

Responses to Crisis and Modernisation. Manchester: Manchester University Press. Marx K (1977) The Civil War in France. In McLellan D (ed) Karl Marx: Selected Writings. Oxford: Oxford University Press. 
Marx K (1977) Critique of Gotha Program. In McLellan D (ed) Karl Marx: Selected Writings. Oxford: Oxford University Press.

Marx K (1977) Wage Labour and Capital. In Marx K and Engels F, Collected Works, Vol. 9, Moscow: International Publishers, pp. 197-228.

Pachter H (1984) Socialism in History: Political Essays. New York: Columbia University Press.

Pannekoek A (1927) Social Democracy and Communism. Accessed at www.marxists.org/archive/pannekoe/1927/sdc.htm.

Pettit P (1997) Republicanism: A Theory of Freedom and Government. Oxford: Oxford University Press.

Pettit P (2006) Freedom in the Market. Politics, Philosophy \& Economics 5(2): 131149.

Pettit P (2012) On the People's Terms: A Republican Theory and Model of

Democracy. Cambridge: Cambridge University Press.

Rahman KS (2017) Democracy against domination: Contesting economic power in progressive and neorepublican political theory. Contemporary Political Theory 16: 41-64.

Rostbøll C (2008) Deliberative Freedom. Albany, NY: SUNY Press. Thompson EP (1963) The Making of the English Working Class. London, Victor Gollancz.

Thompson MJ (2013) Reconstructing republican freedom: A critique of the neorepublican concept of freedom as non-domination. Philosophy \& Social Criticism 39: 277-298.

Thompson MJ (2018) The two faces of domination in republican political theory. European Journal of Political Theory 17(1): 44-64.

Thompson MJ (2018) A Theory of Council Republicanism. In: Muldoon J (ed.) Council Democracy: Towards a Democratic Socialist Politics. London: Routledge, pp. 108-127. 